\title{
Identity Formation in Chinese Christian Churches in the United States
}

\author{
Yi-Hsuan Chelsea Kuo \\ Mercy College, Dobbs Ferry, USA \\ Email: ckuo@mercy.edu
}

Received 21 July 2014; revised 14 September 2014; accepted 30 September 2014

Copyright @ 2014 by author and Scientific Research Publishing Inc.

This work is licensed under the Creative Commons Attribution International License (CC BY). http://creativecommons.org/licenses/by/4.0/

\section{cC) (i) Open Access}

\begin{abstract}
This study looks at some of the Chinese Christian churches of the Boston area by first giving an historical overview and then reporting the findings of the author's fieldwork in a Chinese church in suburban Boston, which is able to shed some light on the many roles Christianity has during the various phases of Chinese immigration and to suggest that it is an ideology which many Chinese immigrants both identify with and reconceptualize in Confucian terms. This Confucian-Christianity has become a common ideology shared by many Chinese Americans: not only the first-generation immigrants who must strive to assimilate but also those second-, third-, and fourth-generation Chinese Americans who join the church largely to partake of the unique communion that it provides and indeed creates.
\end{abstract}

\section{Keywords}

Identity Formation, Immigration, Asian Americans, Sociology of Religion

\section{Introduction}

As the largest Chinese association today in terms of its population, the Chinese Christian church is critical to immigration research. This is all the more true given that the number of Chinese churches in the United States has been increasing rapidly ${ }^{1}$. More than a third of Chinese/Chinese Americans in the United States today are Christians (Yang, 1998), whereas in China they account for just 3 percent of the population. It came as no surprise; therefore, most of the Chinese Christians in the United States converted only after arriving there. This phenomenon stood in contrast to its Korean counterpart, given that most Korean Christians in the States already were Christian before they came there. According to research done by Smith-Hefner (1994), most post-1965 immigrants to the United States from Asia and South and Central America have joined conservative churches. In

${ }^{1}$ For example, in 1970s there were only 66 Chinese churches in Seattle; by 1994, the number had increased to 700. 
other words, Chinese, Korean, and other Southeast Asian immigrants are largely Evangelicals, and Pentecostal Christianity represents the mainstream among Latin American immigrants. That finding is supported by Yang (1998). Given these phenomena, one understands why the relationship between religion and identity is so often deemed to be a potent issue to explore within the immigration master narrative, and why it is so often viewed from a theological or sociological perspective (Suchman, 1992). And yet the studies of Chinese immigrants' conversions have largely been horizontal analyzed, lacking in historical context.

Christianity has had a host of different meanings for Chinese in the United States throughout their long history as American immigrants. The rise of the Chinese church is intertwined with class issues and other factors that are not only matters of belief or religion, and there is no doubt that religion plays a variety of roles in Chinese immigrant communities. This study looks at some of the Chinese Christian churches of the Boston area, first by tracking an historical overview and then by reporting the findings of my fieldwork in a Chinese church in suburban Boston, thereby illuminating the many roles that have been played by Christianity during the various phases of Chinese immigration.

\section{Chinese Christian Communities in the Boston Area: An Historical Overview}

Changes within the Chinese Christian community are closely related to the master narrative of Chinese history, and the organization and ethos of that community reflect the various phases of immigration. By examining some particular communities in the Boston area we will be able to see how they have developed, with their Christian organizations often serving as the center of social life for Chinese immigrants.

There was no salient Chinese immigrant population in Boston until 1875, when some Chinese moved from the west coast to Boston in an attempt to escape the pervasive anti-Chinese sentiment in California. At that time, telephone-company construction was creating many working opportunities for Chinese in Boston (Chu, 1987) and an American missionary movement was trying to reach the Chinese immigrants; the first church organization targeting them in the Boston area was The City Missionary Society, a subordinate organization of the Congregational Church. These missionaries set up English classes and Sunday Schools for the Chinese (85th Annual Report of the City Missionary Society, 1901). Following in the footsteps of the congregational mission, the Baptist Church also set up a Chinese Sunday School in 1893 (Ritchie, 1959), and also sought to instill Christianity by teaching English to these immigrants. Up to this point, the missions were based in Chinatown, and most of their converts were laundrymen, cooks, and waiters. Only a tiny number of Chinese participated in church activities. In 1943, however, the United States revoked the Exclusion Law, and in 1946 Chinese immigration to the United States began to increase substantially; soon five Christian denominations had jointly set up the first Chinese Church in Boston's Chinatown².

Another Chinese Church in Boston, the Boston Chinese Evangelical Church, was built in 1961; most of its members had emigrated from Hong Kong after the communist takeover of China in 1949. Their backgrounds were notably different from those of members of the other Christian churches and Sunday schools. Already there were some professionals in the congregation, although most of its members were drawn from the working class. Indeed, and as I will discuss in detail later, the founding of this church can be viewed as a landmark for Chinese immigrants in transition, in terms of both the composition of the members and the way in which the church was formed and has been run.

The most active organizing factor among Chinese immigrants and students today is Bible-study groups. Among these groups and their affiliated churches, most of the group leaders, preachers, and Sunday-school teachers are Taiwanese. The church with the largest Chinese membership in Boston today is the Chinese Redeemer Church of Greater Boston (pseudonym), which was found in 1961 by the Taiwanese. The latter did not start to immigrate to the United States until 1945, after the Japanese surrender in World War Two. Before that, only a handful of Taiwanese could afford to go abroad to study (Hwang, 1986). After 1949 more and more Taiwanese, fearful that the communists might try to "liberate" Taiwan, came to the United States to study or to immigrate. In stark contrast to that fact, the communist-party takeover in China led to a complete ban on not just immigration but even on study abroad. Thus the old immigrant flow from Chinese mainland soon was replaced by a new one from Taiwan.

Since the 1950s, most of the immigrants from Taiwan have been professionals who have come to the United States to study. Many of the students, young professionals, and families began to get together regularly to share

\footnotetext{
${ }^{2}$ Interview with Mr. Wang Chung-Shien (pseudonym), a teacher of Chinese Sunday School at the Redeemer Chinese Church of Greater Boston.
} 
their feelings and to study the Bible. More than 66 percent of today's Chinese churches in the United States got their start as Bible-study groups (Huang, 1986). Thus, most of them are nondenominational. The composition of these churches has been different from that of the Chinatown-based ones founded in the 1940s and 1950s. The people in the Bible-based congregations convened from different neighborhoods and thus socioeconomic backgrounds, and this change reflects the transformation of Chinese immigration during the period. Chinatown already had gone from being a ghetto where people had converged due to a common language, to an information resource center (Kwong, 1997). Boston's Chinatown today is more like a tourist attraction, given its exotic images, cheap and delicious food, services for newer immigrants, and economic enclaves of Chinese people (Zhou, 1992). In recent decades the Chinese churches in Boston have been built outside of Chinatown, thereby reflecting the new residential pattern of these immigrants; they have functioned, especially in the form of fellowships, as information exchanges and providers of cultural comfort. Fellowships based on common residential areas are perhaps the most crucial component of this new style of church. Today there are twenty-four Chinese-speaking and ten English-speaking Christian fellowships within the Chinese Redeemer Church of Greater Boston. These fellowships are variously based on geographical locations ${ }^{3}$, ages ${ }^{4}$, and schools ${ }^{5}$, but invariably are very family oriented in terms of the message they convey; there also are four Chinese fellowships for women, based on their geographical areas, and several family fellowships that are conducted in both Chinese and English. When these Chinese churches are looked at from this perspective, they are seen to represent an "alternative Chinatown," one that provides a host of services to Chinese immigrants and constitutes an important link in the broader chain of Chinese churches.

As has been true of most Chinese churches in the United States, in the beginning the congregation of the Chinese Redeemer Church of Greater Boston consisted chiefly of Taiwanese. Since the 1980s however, and the opening of China by Deng Shiaoping, more people from mainland China have joined the congregation. Most of these mainland Chinese have been students, visiting scholars, and young professionals, with no special religious preference. In one striking regard these new converts were different from those who had emigrated prior to 1949: Owing to the influence of communist ideology during the Cultural Revolution and the subsequent series of political events and movements, many of these mainland Chinese never had a chance to learn about Christianity before they came to the United States. As noted above, most of the Sunday-school teachers, leaders of Bible-study groups, and pastors have been Taiwanese due to historical and cultural factors, but in recent years the number of mainland Chinese in the churches has increased dramatically. These people have not only participated actively in church affairs but also have accepted Christianity more easily than have most Taiwanese people 6 . Two reasons can be adduced to explain this enthusiasm. First, a series of movements forbade or at least severely constrained belief in traditional deities and folk religions, beginning with the May Fourth movement in 1919 and continuing with the Cultural Revolution and the communist movement in general in China. Second, since the 1970s, Chinese leaders have lessened the flow of socialist ideology to China's people. Given this ideological vacuum, many Chinese people have tended to accept Christianity more easily (Yang, 1988). For them, Christianity represents what they perceive to be the two drivers of western civilization: modernity and democracy ${ }^{7}$.

We can conclude, in summing up the previous historical review, that there were three phases in the foundation of the Chinese Christian community in Boston. In the $19^{\text {th }}$ century, Chinese Christian communities were based in Chinatown along with the majority of the Chinese population, and were a part of the American church. In the early $20^{\text {th }}$ century, Chinese churches were built up with the support of American denominations, but beginning in the 1960s, Chinese churches in the United States entered a new phase, in that most were founded independently. Although Taiwanese Churches are primarily denominational, owing to the specific historical contexts in which they arose, they too have tended to begin with Bible-study groups founded by students or families ${ }^{8}$. In

\footnotetext{
${ }^{3}$ For example the Acton Area Fellowship, Alewife Fellowship, Brookline Fellowship, and Burlington Fellowship. In all there are nineteen such fellowships based upon location.

${ }^{4}$ For example the Chen-kwang Fellowship for young parents, She-ching Fellowship for young professionals, the Zion Fellowship for elders, and the Youth Fellowship in English.

${ }^{5}$ In the case of students, their fellowships are all held in English. For example, the Chinese Bible Fellowship at MIT, and the Inter-College Fellowship.

${ }^{6}$ Interview with a missionary of China Ministries International, Tim Conkling.

${ }^{7}$ Interviews with congregants in the Chinese Bible Church of Greater Boston. Also, interview with a witness to the Lu-Gang incident, in a broadcast of a Chinese Christian station in the United States.

${ }^{8}$ Some Churches are driven to join a domination because of financial constraints. A good example in this regard is the way the Boston Taiwanese Christian Church joined the Reformed Church.
} 
sum, Chinese churches in the United States have changed from being denominational to nondenominational, and from being Chinatown-based to suburban. They also have changed in terms of their members' occupations and the purposes for which they go to church. The congregations of the churches founded after the 1960s consist mostly of professionals and those from the higher classes, whereas the first Chinese churches often drew their congregations from those on the lower socioeconomic levels and having more heterogeneous backgrounds.

\section{3. "Church-Built-Chineseness": Confucian Orthodoxy vs. Evangelical Christianity}

The conversion of the Chinese to Christianity is not simply a matter of indigenization or contextualization as most missionaries have said, but rather a process that entails an active adoption on the part of the convert. Christianity, just like Confucian values, has been actively interpreted by the Chinese throughout history.

My observation of the congregation at the Chinese Redeemer Church of Greater Boston confirms the latter hypothesis. Chinese participate in church activities for a whole host of reasons. Chinese Americans usually can choose to be part of either of two congregations in Chinese churches. In one the service is conducted in Mandarin/Cantonese/Taiwanese, in the other in English. Those who go to the Mandarin service usually are first-generation immigrants, while those who go to the English service usually are American-born Chinese. Many new immigrants come to Chinese churches for help, and thus these churches have gradually become the first places in which immigrants make vital contacts after moving to a new area or immigrating to the United States. Some people look for the webpage of the local Chinese church and post a message asking for help in settling in ${ }^{9}$. In the case of the Chinese Redeemer Church of Greater Boston, on the church's information card, which is filled out by those who have come there for the first time, a question asks "Do you need anyone to help you to settle down?” The church is actively paying attention to new immigrants and reaching out with an offer to help. Indeed, by going to a Chinese church, the new immigrants can not only receive actual help, but also build up their social network within a short period of time. In the Sunday-school classes and fellowships, people can make friends easily. As I argued in the previous section, the Chinese churches tend to draw people of a certain similar background. Many go to church or join fellowships for social purposes, so as to find people who are from the same country or at least speak the same language ${ }^{10}$. Others are interested in Christianity because they could not gain access to it when they were in China, and thus are curious or even eager to know what Christianity is all about. They see joining a the Christian church as a good way to make friends, obtain help, and learn more about that American culture which sometimes seem to be synonymous with Christianity ${ }^{11}$. An informal exchange of information on matters such as jobs and houses is continually transpiring in the Chinese churches, and the fellowships are always providing social comfort to these immigrants.

A salient fact revealed by my interviews with parishioners at the Chinese Redeemer Church of Greater Boston is that a great many people go to church chiefly for the benefit of their children. More specifically, Chinese American parents encourage their children to go to Chinese church because they believe the message conveyed is family oriented, which conforms to Chinese values. "Going to a Christian church is good," said a mother. "If they [children] accept the teachings in the Bible, they will know how to be loyal to their parents." On the church's side, the preacher carefully negotiates certain messages in the Bible that seem to conflict with Chinese values. For example, when in the course of his sermon given at Sunday worship the preacher of the Chinese Redeemer Church of Greater Boston came to Luke 14:26, "If anyone comes to me without hating his father and mother, wife and children, brothers and sisters, and even his own life, he cannot be my disciple," he alluded to the Chinese idea of yi-shaio-tsuo-chung (meaning that at the highest level filial piety is transformed into devotion to one's nation) to explain why Jesus had said this. "Jesus does not mean that we do not have to be filial to our parents. [He means] just like yi-shaio-tsuo-chung: only if you make Jesus the first priority in your life can you know how to be filial to your parents. Thus parents expect that church attendance will explicitly convey Christianity and implicitly pass on "Chineseness," namely some selected traditional values, to their children. One of my informants put it this way: "If the children go to the church, they will learn more about renqing shihgu [interpersonal behavior], because church is a place full of reqingwei [human feeling].” The former term refers to "social norms and moral obligations" while the latter one means the "basic emotional responses of an individual” (Yan, 1996).

\footnotetext{
${ }^{9}$ For example, the webpage of Dayton Chinese Christian Church has a column for people seeking assistance in settling in. See www.immanuel.net/DCCC/

${ }^{10}$ Interview with congregants of the Chinese Redeemer Church of Greater Boston.

${ }^{11}$ Interview with the Chinese participants in Chinese Redeemer Church of Greater Boston.
} 
Most parents hope to pass these basic Chinese values on to the second generation by joining Chinese Christian churches, but some also want their child to connect with the mainstream American ideology and bring their children to a Chinese church for that purpose. A man told me that "I do not believe in God, but since I am living in this Christian country [the United States], I think it is good for my daughter to know a bit of Christianity; thus I have my wife bring her to church kindergarten.” Many first-generation immigrants hope their children will be able to integrate into mainstream American society; they think that being a Christian, or at least going to church, makes their children "more Americanized." Another strong force driving church attendance, however, is parents' desire that their children meet the "right people." Most parents who are first-generation immigrants find it hard to accept interracial marriages for their children. Thus Chinese church is the perfect place to ensure that their children will meet, and ultimately mate with, a Chinese man or woman. The church's use as a de facto dating center feels all the safer to them, owing to such sexually related doctrine as the sanctions against premarital sex and divorce.

The above-cited reasons explain why first-generation immigrants go to Chinese church and stipulate that their offspring must do likewise. What they do not explain is the ever-increasing numbers of native-English-speaking Americans filling the various congregations of the Chinese Church. Let us again take the Chinese Redeemer Church of Greater Boston as our example; many people in the congregation are third- and even fourth-generation Chinese Americans who have no idea where their great-grandparents originated from in China. These people still go to Chinese church, even though there are no adjustment problems for them, because they are American-born and even though their parents are not trying to steer them away from interracial marriages ${ }^{12}$. In the case of these third- and fourth-generation Chinese Americans, their affiliation with Chinese churches represents not only their search for a social network capable of producing material benefits, and a vital information exchange serving as a mode to assimilation into American culture, but also a quest for ethnic belonging. One of my informants from the Chinese Redeemer Church of Greater Boston, a volunteer shuttle-bus driver who picked up people from the Alewife T station and brought them to the church, and a fourth-generation Chinese American, said this when I asked him where he was from: "I am from Massachusetts. I have lived in my house in South Boston ever since I was born. I am not sure where my great-grandfather came from in China, but my father told me they do not speak Mandarin but rather a local dialect, I am not sure what dialect that is-maybe a sort of Cantonese. Actually I do not even know my great-grandfather, the one who first came to the States, or when my great-great-grandparents came here." In the course of our conversation he stressed several times that he does not know anything about China or Chinese culture: "I've never left here my whole life, not even to go to Maine! Even my grandfather did not know how to speak Chinese.” When I asked him, "what brought you to this Chinese church?" he responded thus: "I have also been to other American churches for Sunday worship, but I like the teachings here more."

Another informant, also a fourth-generation Chinese American, said this to me: "Yes, I can meet more people who have the same background as me, but the main reason for me to come to this Chinese church and the Chinese student fellowship is that I think the Christianity conveyed in Chinese churches is more original, and maybe is more strict and authentic.” In the Chinese Redeemer Church of Greater Boston the pastor often criticizes the immorality of contemporary American values, saying that the problems of American society are due to the decline of Christianity, with most Americans merely knowing the teachings of the Bible while not following them ${ }^{13}$. "In fact, those Americans do not really understand Jesus' teaching." ${ }^{14}$ Indeed most Chinese Christians say that although America is a Christian society, most Americans are not "true Christians" (Yang, 1998). They think that "the reason why American society has become so chaotic (luan) is because Americans have already lost the essence of Christianity in their society." ${ }^{, 15}$ Luan, a central theme of Confucianism, refers to disorder in social relations and political affairs (Watson, 1982). Thus these Chinese immigrants see Christianity being as the best way of staving off disorder/chaos and achieving the ideal Confucian universe.

More than 80 percent of the readers of Hao-Jiao are not Christian ${ }^{16}$. Its popularity among Chinese Americans represents their need to hear this kind of voice emanating from Chinese immigrant society. This publication ful-

\footnotetext{
${ }^{12}$ Interviews with several third-generation Chinese Americans. Among the nine of them, six said that their parents did not care if their wife/husband turned out to be of another race. Two said that their parents preferred Asians, and one said that her parents wanted her to marry a Caucasian or an Asian.

${ }^{13}$ Sermon at Redeemer Chinese Church of Greater Boston.

${ }^{14}$ Chinese Christian Herald Crusade, Hao-Jiao (Bugle), 1998a.

${ }^{15}$ Sermon at Chinese Redeemer Church of Greater Boston.

${ }^{16}$ Sermon at Chinese Redeemer Church of Greater Boston.
} 
fills a very practical function by answering questions on legal issues via the professional lawyers on the newspaper's staff, especially questions related to immigration law, family problems, and money matters. Indeed, it practicality extends even into the sphere of church-going, for instead of promoting the grace of Jesus Christ it tends to encourage readers by citing scientific figures indicating that "praying or having Christian beliefs is good for one's health," ${ }^{, 7}$ and that children and teenagers who go to church tend not to be seduced by drugs ${ }^{18}$ or violence $^{19}$. The church also provides these immigrants with a set of values for them to hold on to. In their eyes Christianity is more of a modality for solving or avoiding life's everyday problems than it is an abstract theological and spiritual system. Ultimately, it seems to be a way for them to maintain and somewhat reinvent their existing values.

Thus, the Chinese Churches in the United States have their own ideologies and values, that differ in many ways from those of the mainstream American churches. As noted earlier, almost all of them are Evangelical, not American mainstream liberal, churches. The Evangelical Protestant church is a conservative branch of Christianity which preaches that attaining a personal faith in Jesus Christ is the only way in which people can attain redemption. It focuses more on moral education and family values and less on issues of social justice and gaining an on academic, rational understanding of the Bible ${ }^{20}$. The fact that most Chinese churches are Evangelical cannot be entirely explained by saying that Evangelical Christian missionaries have worked harder to convert the Chinese than have the ministers of liberal churches, although there is some truth to that assertion. What is behind the acceptance of Evangelical Christianity by the Chinese is that, first, conservative religions do a better job of helping people to absorb the impact of modernity, according to Nancy Ammerman (Ammerman, 1987). Evangelical Christianity attracts Chinese immigrants by the absoluteness and certainty of its belief-system and by its provision of solid values. Second, Evangelical Christianity is compatible with Confucian orthodoxy in many ways (Yang, 1992). Confucianism is indeed an orthodoxy for Chinese; although they do not always follow it, when they find themselves confronting an unfamiliar culture they reassert their existing values and strive to pass at least a few selected ones down to their American-born children. Evangelical Christianity's emphases on the value of family, on moral education, and on the Protestant ethic of "this-worldly asceticism" creates a surprisingly strong bond with Confucianism. At any rate, the Chinese churches have always stressed the compatibility of the two ideologies (Yang, 1992).

This "Confucian Christianity" provides Chinese Christians with such a sense of identity that it tends to become a central orthodoxy even for American-born Chinese. This what I called "church-built Chineseness," for over a century now it has been providing a shared identity for immigrant Chinese Christians in the United States of the first, second, third, and fourth generations.

\section{Conclusion}

Our exploration of the community spread across the Boston Chinese churches has shown that Christianity is an ideology that many Chinese immigrants both identify with and reconceptualize in Confucian terms. This "Christianity with a Chinese character" has been created via a host of factors, two of the main ones being the historical transformation of Chinatown and the practical help that the churches have rendered their parishioners in meeting their social and psychological needs. Thus Chinese Christian churches attract not only first-generation immigrants who must strive to assimilate into mainstream American society but also those second-, third-, and fourth-generation Chinese Americans who join the church largely to partake of the unique communion that it provides and indeed creates.

In asserting that Confucian-Christianity has become a common ideology shared by many Chinese Americans, this study by no means seeks to deny either that Christianity has had a broad range meanings for Chinese throughout their long history as American immigrants or that many Chinese Americans sincerely hold Christian beliefs. Ultimately, however, going to a Chinese church simply provides many immigrants with an invaluable opportunity to consider and to display their class, their political inclinations, and their unique position within

\footnotetext{
${ }^{17}$ Chinese Christian Herald Crusade, Hao-Jiao (Bugle), 1998 b.

${ }^{18}$ Chinese Christian Herald Crusade, Hao-Jiao (Bugle), 2014a.

${ }^{19}$ Chinese Christian Herald Crusade, Hao-Jiao (Bugle), 2014b.

${ }^{20}$ The divergence of Evangelical and Liberal Christianity sprang from their different responses to the Renaissance, which placed a high value on rationality and believed in people's ability to be rational. Liberal Christianity was prompted by the spirit of the Renaissance to question all faith-related matters and to use reason to interpret the Bible, while Evangelical Christianity stick to what they had believed and emphasized the need for a supra-rational faith.
} 
American society. In other words, by partaking of and thereby sustaining Confucian Christianity, they attain a Church-oriented identity that transcends even the seeming orthodoxy of Confucian Christianity.

We have found in this study that the rise of the Chinese church has always been intertwined with class issues and other factors that are not just matters of belief or religion. Anderson (1983) emphasizes the "imagined" nature of nationalism, and I would contend that when it comes to these Chinese immigrants, Christianity exactly subserves this function of imagination. For instance, young Chinese Christians studying in the United States in the early $20^{\text {th }}$ century took Christianity, an essential component of modernity, and upon its ideological base strove to construct first an image, and ultimately the reality, of China as a modern nation-state. And for the Chinese Christian community of today, Christianity is a metaphor, a meaning-creator and -reinventor, as much as - or more than - it is a religion in the sense of a relatively rigid belief-system that the worshiper "must" buy into in its totality. That theory must be supplemented by another, however, for conversion to some extent fits that model of a consumption culture, facilitating the transformations of nation-states, which has been advanced by Appadurai (1996). By “consuming” Christianity, America's immigrants of Chinese origin have long been able to both adapt themselves to western modernity and attain a sense of mutual belonging and unique identity.

\section{References}

Ammerman, N. T. (1987). Bible Believers: Fundamentalists in the Modern World. New Brunswick, NJ: Rutgers University Press.

Anderson, B. (1983). Imagined Communities: Reflections on the Origin and Spread of Nationalism. London: Verso.

Appadurai, A. (1996). Modernity at Large: Cultural Dimensions of Globalization. Minneapolis: Minnesota Press.

Chu, D. C. J. (1987). Chinese in Massachusetts: Their Experiences and Contributions. Boston: Chinese Culture Institute.

85th Annual Report of the City Missionary Society (1901). Boston.

Hao-Jiao (Bungle) (1998a). Chinese Christian Herald Crusade.

Hao-Jiao (Bungle) (1998b). Chinese Christian Herald Crusade.

Hao-Jiao (Bungle) (2014a). Chinese Christian Herald Crusade.

Hao-Jiao (Bungle) (2014b). Chinese Christian Herald Crusade.

Hwang, W. T. (1986). Beimeicho Taiwan Qiduqiaohui Kaituoshi. (A History of the Development of Taiwanese Christian Churches in North America.) Los Angeles: Taiwanese Christian Church Council of North America.

Kwong, P. (1997). Forbidden Workers: Illegal Chinese Immigrants and American Labor. New York: The New Press.

Ritchie, C. M. (1959). First Baptist Church to Mark Founding of Chinese Sunday School. Back Bay Ledger, 7 May 1959.

Smith-Hefner, N. (1994). Ethnicity and the Force of Faith: Christian Conversion among Khmer Refugees. Anthropological Quarterly, 67, 24. http://dx.doi.org/10.2307/3317275

Suchman, M. C. (1992). Analyzing the Determinants of Everyday Conversion. Sociology of Religion, 53, S15-S33. http://dx.doi.org/10.2307/3711248

Yan, Y. (1996). The Flow of Gifts. Palo Alto: Stanford University Press.

Yang, F. (1988). Chinese Conversion to Evangelical Christianity: The Importance of Social and Cultural Context. Sociology of Religion. Washington.

Yang, F. (1992). Religious Conversion and Identity Construction: A Study of a Chinese Christian Church in the United States. Washington DC: The Catholic University of America.

Yang, F. (1998). Chinese Conversion to Evangelical Christianity: The Importance of Social and Cultural Contexts. Sociology of Religion, 59, 237-257. http://dx.doi.org/10.2307/3711910

Zhou, M. (1992) Chinatown: The Socioeconomic Potential of an Urban Enclave. Philadelphia: Temple University.

Watson, J. L. (1982). Of Flesh and Bones: The Management of Death Pollution in Cantonese Society. In M. Bloch, \& J. Parry (Eds.), Death Ritual in Late Imperial and Modern China (pp. 155-186). Cambridge: Cambridge University Press. 
Scientific Research Publishing (SCIRP) is one of the largest Open Access journal publishers. It is currently publishing more than 200 open access, online, peer-reviewed journals covering a wide range of academic disciplines. SCIRP serves the worldwide academic communities and contributes to the progress and application of science with its publication.

Other selected journals from SCIRP are listed as below. Submit your manuscript to us via either submit@scirp.org or Online Submission Portal.
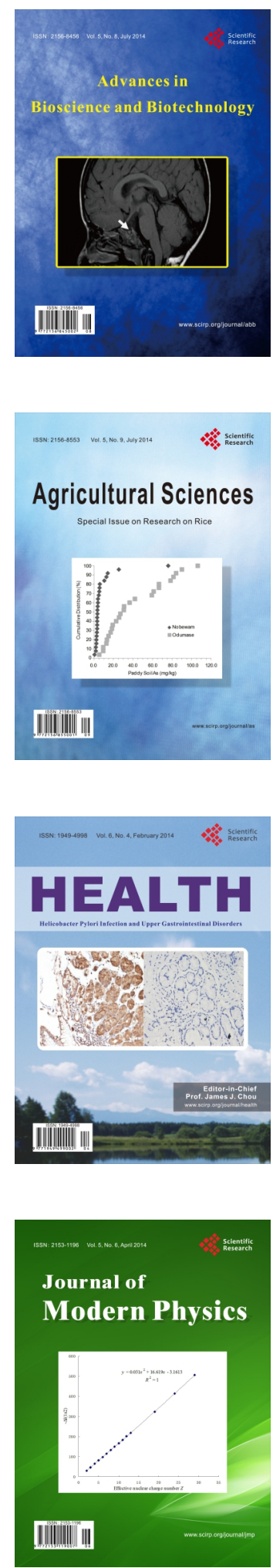
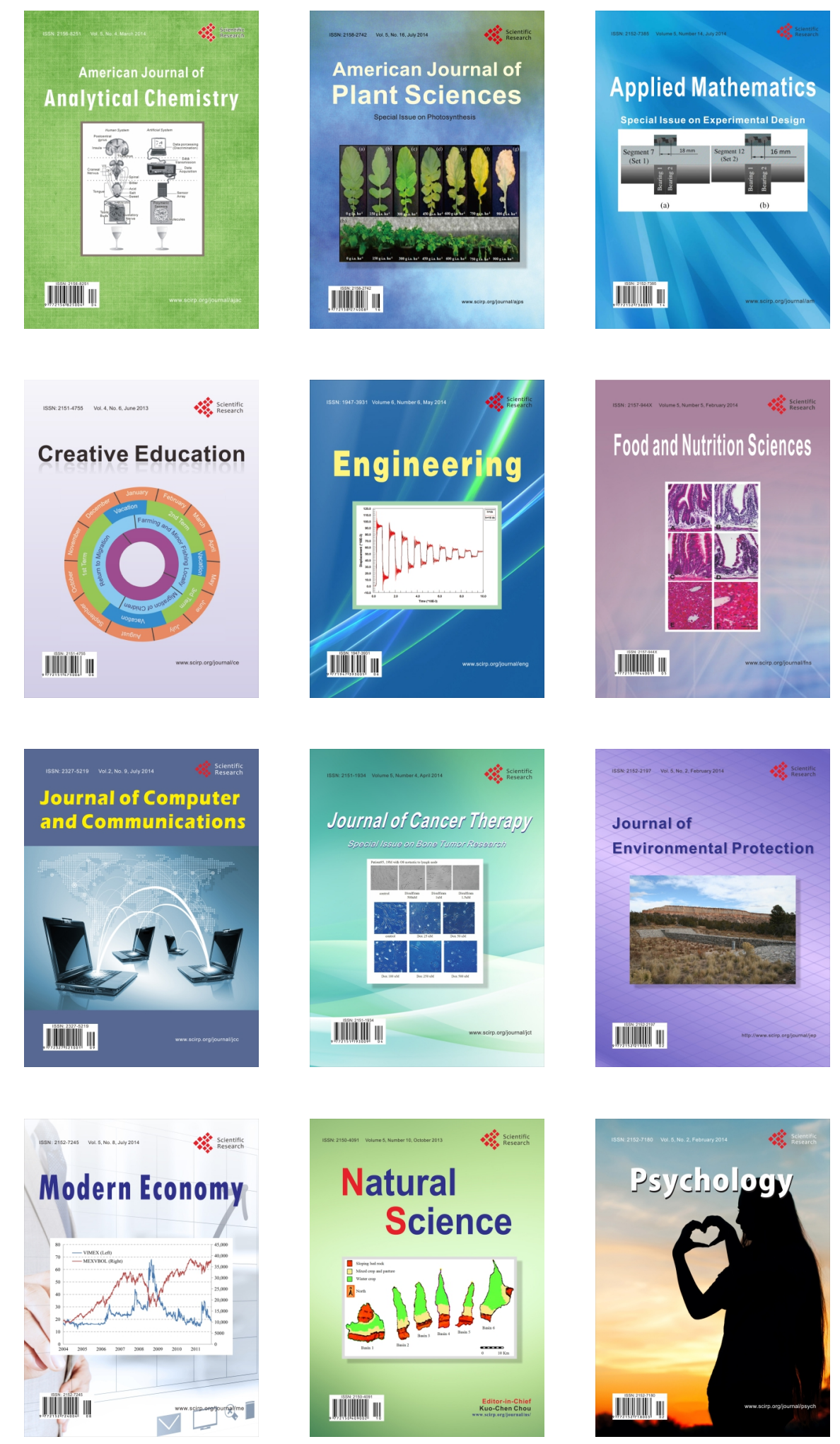